Environment Conservation Journal 20 (1\&2) 51-56, 2019

ISSN 0972-3099 (Print) 2278-5124 (Online)

Abstracted and Indexed

\title{
Spatial analysis of ground water level and fluctuation at regional level in North-East of Haryana: Reference to Karnal District, India
}

\author{
Kumar S. ${ }^{1}$ 凶, Singh A. ${ }^{2}$ and Kaur N. ${ }^{1}$
}

Received: 25.08 .2018

Revised: 28.11.2018

Accepted: 10.01.2019

\begin{abstract}
The study was conducted to found the ground water potentials in Karnal district of Haryana with an aerial extent of 2520 sq. km. The study has analysed the spatial-temporal changes in groundwater depth in Karnal district to understand the hydrological behaviour and status of the area. Various thematic maps were prepared such as (Groundwater and its fluctuation of pre-monsoon and monsoon in two decades (1996-2017). The main objective of the study was to investigate the temporal trends in annual and monthly groundwater level with the help of central ground water board data. The result indicate a mix of negative and positive trends in the ground water level series.
\end{abstract}

Keywords: Groundwater level, fluctuation, pre-monsoon and monsoon, average, GIS

\section{Introduction}

Oscillatory water-level fluctuations are reversible changes in water levels around a long-term mean (Arnold and Valk, 2005). Groundwater is a dynamic and replenishing natural resource. But in hard rock terrains, availability of groundwater is of limited extent. Occurrence of groundwater in such rocks is essentially confined to fractured and weathered horizons. In India and certain parts of the world, water crisis is becoming a regular phenomenon, perhaps due to improper scientific management of water resources leading to continued environmental degradation (Bhutiani et al., 2018). Poor knowledge about this resource, because of its hidden in nature and its occurrence in complex subsurface formations, has been and is still a big obstacle to the efficient management of this important resource. In India, 65 per cent of the total geographical area is covered by hard rock formation with low porosity (less than 5 per cent) and very low permeability (Saraf and Choudhary, 1998). Therefore, efficient management and planning of groundwater in these areas is of utmost importance. An extensive hydro geological investigation is required for through understanding

\section{Author's Address}

${ }^{1}$ Department of Agricultural Meteorology, CCS Haryana Agricultural University, Hisar

${ }^{2}$ Govt.S.S.S, Nehla, Fatehabad

E-mail.: surenderchahal299@gmail.com of the groundwater conditions. The Remote Sensing and GIS tools have opened new paths in water resources studies. Remote sensing provides multispectral, multi-temporal and multi-sensor data of the earth surface (Choudhary, 2003). Remote Sensing and GIS in hydrological investigations and monitoring is very crucial for successful analysis, prediction and validation (Sharma and Saraf, 2002).

\section{Study area}

Karnal district is located between $29^{0} 25^{\prime} 05^{\prime}$ 'to $29^{\circ} 59^{\prime} 20^{\prime \prime}$ North latitudes and $76^{\circ} 27^{\prime} 40^{\prime \prime}$ to $77^{\circ} 13^{\prime} 08^{\prime}$ ' East longitudes and covering an area of 2520 sq. km. Karnal district covers $5.69 \%$ area of the state. The district is bordered by the river Yamuna in the east, Panipat district in the south, Kaithal district in the west and Kurukshetra district in the north. The district is well connected by roads and railways. Karnal is the district headquarters. The main townships are Karnal, Indri, Assandh, Nissang, Nilokheri, and Ghauranda. The district is a part of the Indus- Ganges plain (Upper Yamuna Basin) and has a well-spread network of western Yamuna canals. Its geographical area has been divided into three regions: Khadar, Bangar and Nardak belt. The river Yamuna which marks the eastern boundary of the Haryana State as well as Karnal district provides the major drainage in the area. Irrigation in the district is done by surface 
water as well as ground water. $70 \%$ of the net irrigated area is covered through ground water.

\section{Materials and Methods}

The study is analytical in nature and based on secondary sources information. Major sources of data were ground water year data published by Central Ground Water Board and Ground Water Cell, Agricultural Department, Government of Haryana and statistical abstract of Haryana. The study was carried out for period of last 2 decades (1996-2017). Six stations/ground water observations well were selected from each block in the Karnal district. The selected observation wells were Amin, Kalri jagir, Kachhwa, Jundla, Garhi khajur and Mound falling in Assandh, Gharaund, Indri, Karnal, Nilokheri and Nissang blocks respectively.. The major activities involved in this process include compilation of existing data, generation of GIS database (shape files), interpolation, categorization, mapping and interpretation.

\section{Result and Discussion}

Results of the study are self-explanatory form various maps prepared in the study (Fig. 1 to 5). For better understanding the interpretation was carried out for long period average groundwater level for seasons (pre monsoon and monsoon), current groundwater level i.e. year 2017 and fluctuation of current groundwater level from its long period average.

Ground water status during Pre-Monsoon Period

Average of ground water level during premonsoon period: The long term pre-monsoon data was analyzed by averaging the last 2 decades (1996-2017) water level data. During pre-monsoon ground water level in the district was ranging from 4 to 25 meters bgl (fig 1) Water table at Kalri jagir, Kachhwa, Jundla was higher as compared to other parts of district. Southern part of district had higher GW level from north parts.

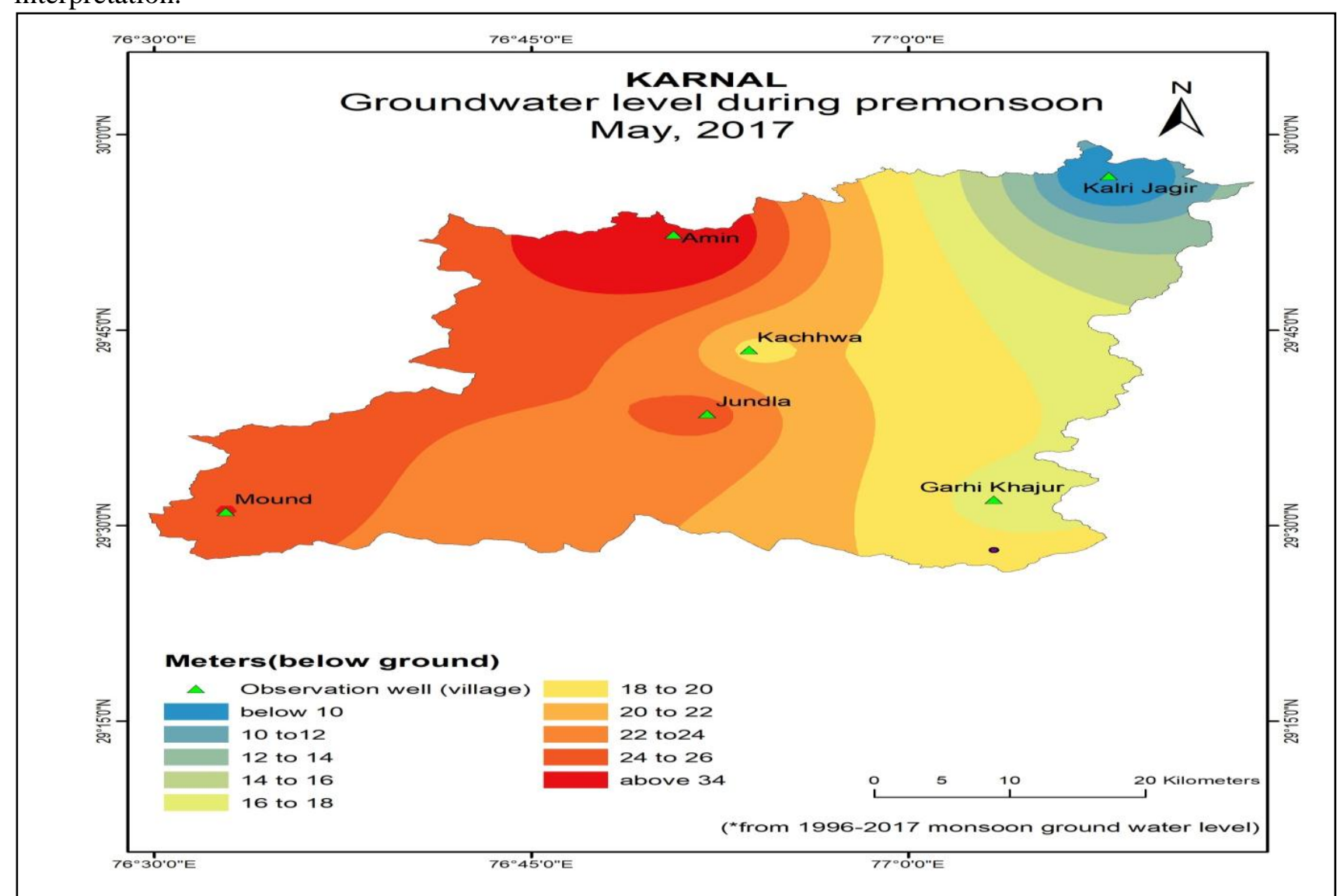

Figure 1. Average ground water levels during pre-monsoon period GW level 1996-2017 


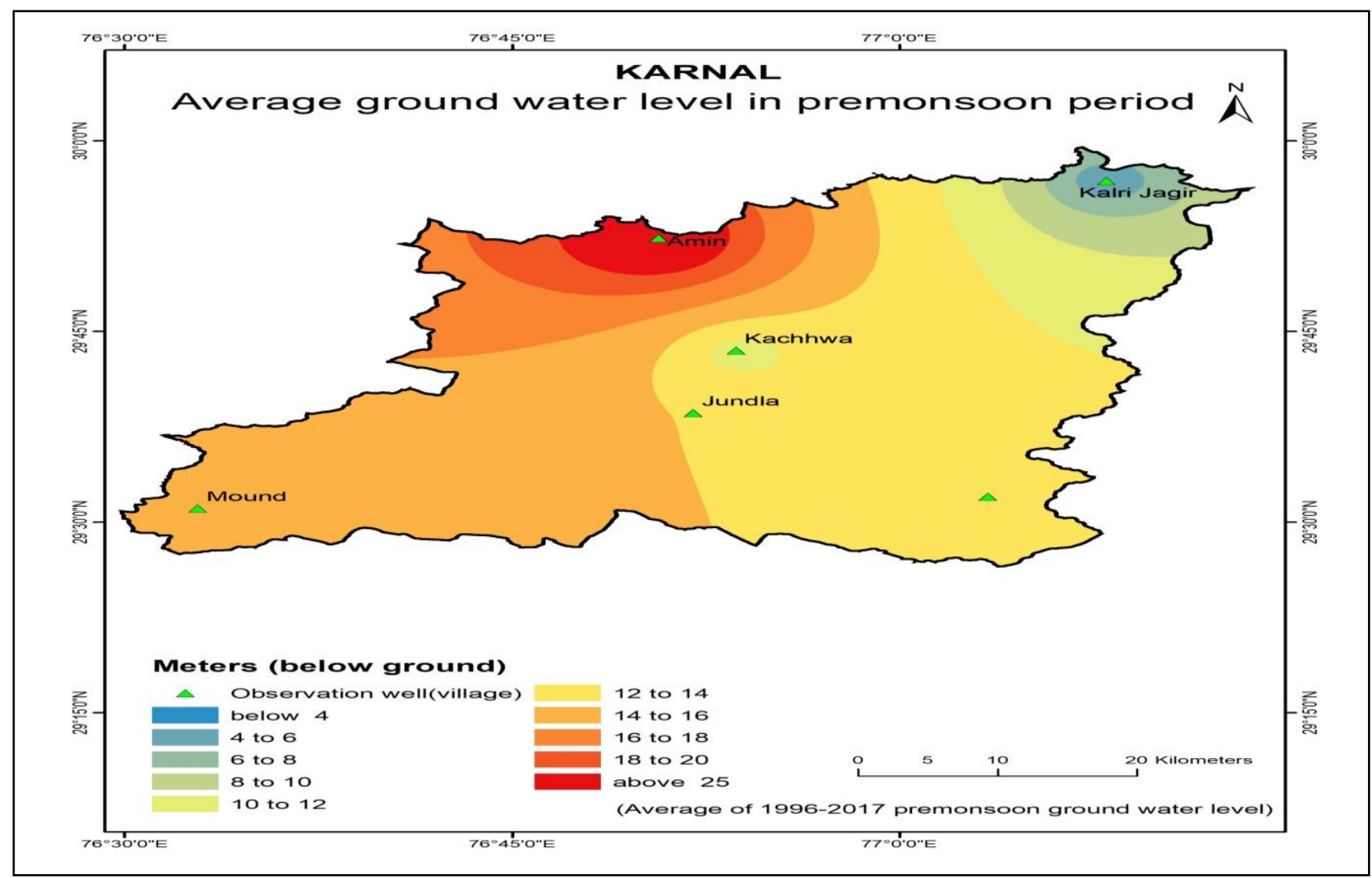

Figure 2. Ground water levels during pre-monsoon 2017

Table 1. Groundwater level and fluctuation in different station in Karnal district

\begin{tabular}{|l|l|l|l|l|l|l|l|}
\hline STATION & Block & $\begin{array}{l}\text { Ground } \\
\text { water level } \\
\text { pre- } \\
\text { monsoon- } \\
\mathbf{2 0 1 7} \text { (bgl } \\
\text { mts.) }\end{array}$ & $\begin{array}{l}\text { Ground } \\
\text { water } \\
\text { level } \\
\text { monsoon- } \\
\mathbf{2 0 1 7}(\mathbf{b g l} \\
\text { mtss) }\end{array}$ & $\begin{array}{l}\text { Average } \\
\text { Ground } \\
\text { water level } \\
\text { pre-monsoon } \\
\text { (last } \\
\text { decades) }\end{array}$ & $\begin{array}{l}\text { Average } \\
\text { Ground } \\
\text { water level } \\
\text { monsoon } \\
\text { last 2 } \\
\text { decades) }\end{array}$ & $\begin{array}{l}\text { Ground } \\
\text { water level } \\
\text { fluctuation } \\
\text { in } \\
\text { pre- } \\
\text { monsoon }\end{array}$ & $\begin{array}{l}\text { Ground } \\
\text { water level } \\
\text { fluctuation } \\
\text { in } \\
\text { monsoon }\end{array}$ \\
\hline Mound & Assandh & 26.11 & 20.21 & 15.94 & 14.83 & -10.17 & -5.38 \\
\hline Garhi Khajur & Gharaunda & 16.85 & 17.5 & 13.4 & 13.8 & -3.45 & -3.7 \\
\hline Kalri Jagir & Indri & 4.9 & 3.55 & 4.506 & 4.48 & -0.394 & 0.93 \\
\hline Kachhwa & Karnal & 19.45 & 14.45 & 11.24 & 9.36 & -8.21 & -5.09 \\
\hline Amin & Nilokheri & 34.07 & 27.15 & 25.63 & 22.2 & -8.44 & -4.95 \\
\hline Jundla & Nissang & 25.03 & 18.09 & 13.8 & 13.07 & -11.23 & -5.02 \\
\hline
\end{tabular}

Ground water level in pre-monsoon 2017: at Amin station. Whereas, in eastern part it was During pre-monsoon 2017 the ground water level about $10 \mathrm{~m} \mathrm{bgl}$ around Kalri jagir station of Karnal was found from 10 to $24 \mathrm{~m} \mathrm{bgl}$ in the district (fig 2) district.

in the north ground water level was at $34 \mathrm{~m} \mathrm{bgl}$ 
Fluctuation in ground water during pre- ground water level of pre-monsoon 2017 from its monsoon (2017) with respect of average level- long time average (1996-2017). Rise in water level Ground water fluctuation in pre-monsoon period was found in north parts and decline was in south was found between -11 to $4 \mathrm{~m}$. District observed eastern parts. Western parts of district had rising mix pattern of rising as well as declining trends of level as shown in map (fig 3).

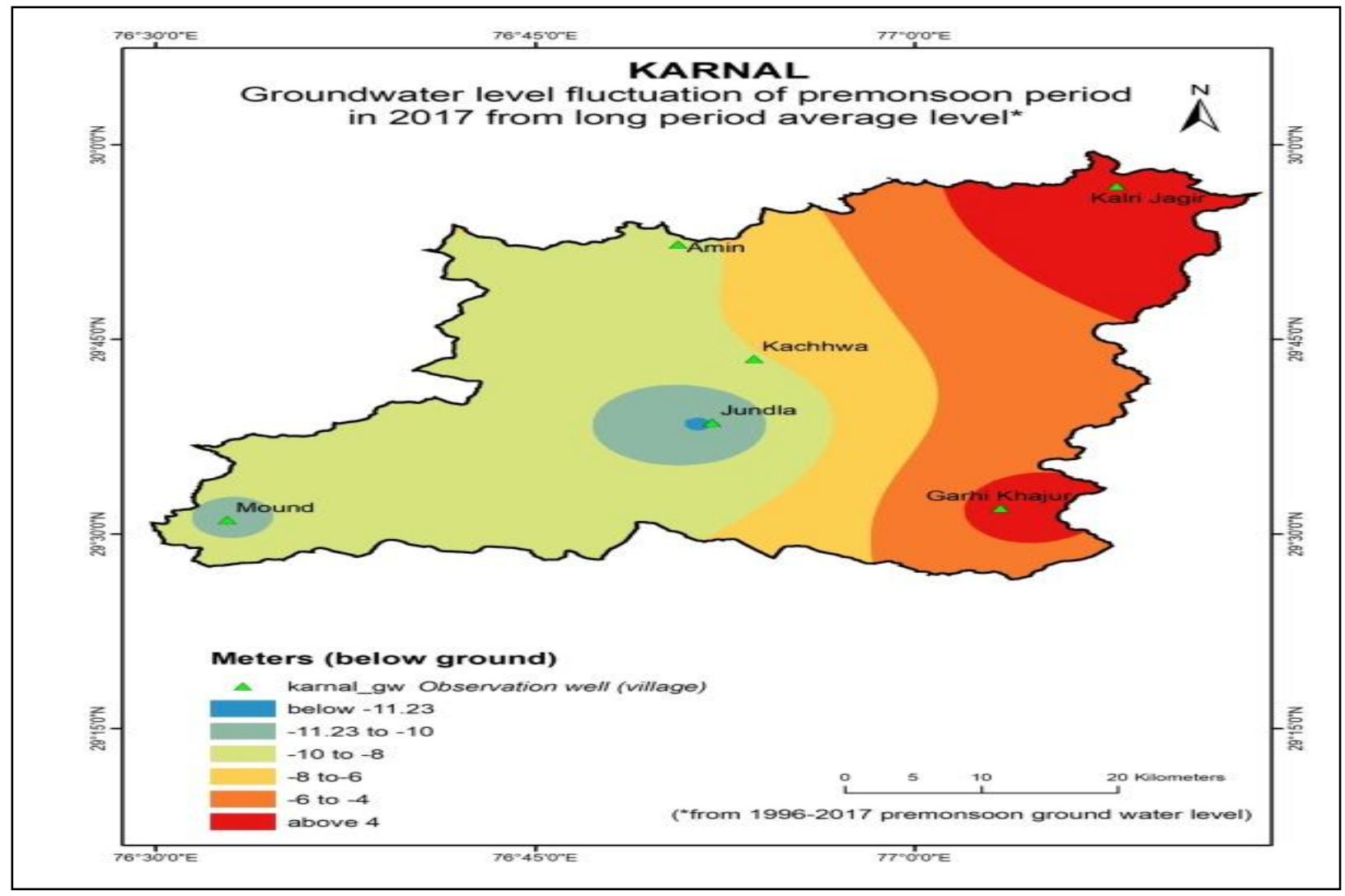

Figure 3. Fluctuations in GW levels in pre-monsoon period 2017 from average.

Ground water status during Monsoon Period Average ground water level during monsoon period: - Average groundwater depth was determined by averaging the long period (19962017) ground water level. During monsoon period, average ground water Ground water level in the district remained 6-18 meters below ground. Minimum depth of Ground water was about $6 \mathrm{~m}$ around Indri block (Kalri jagir station) in eastern part of Karnal district. The groundwater depth increases with distance from Yamuna River and observed more than $22 \mathrm{~m} \mathrm{bgl}$ in some parts. The monsoon period ground water level in Karnal district was 10-14 m bgl in most parts (fig. 4).
Ground weater level in Monsoon 2017:- In monsoon period i.e. August, highest ground water level was found at Kalri jagir station (4 m bgl). In Amin ground water level was $27 \mathrm{~m}$ bgl. In the most of Karnal district, ground water level was found between 4 to 27 meters or more. Southern parts of district had slightly deeper water level as compared to north parts (fig 5).

Fluctuation ground water level during monsoon (2017) with respect average level:- Fluctuation of current year water i.e. 2017 was compared with long period average water level in monsoon period for better estimation of fluctuation (Fig. 6) reveals that large area within district observed declining water level up to $5 \mathrm{~m} \mathrm{bgl}$. 


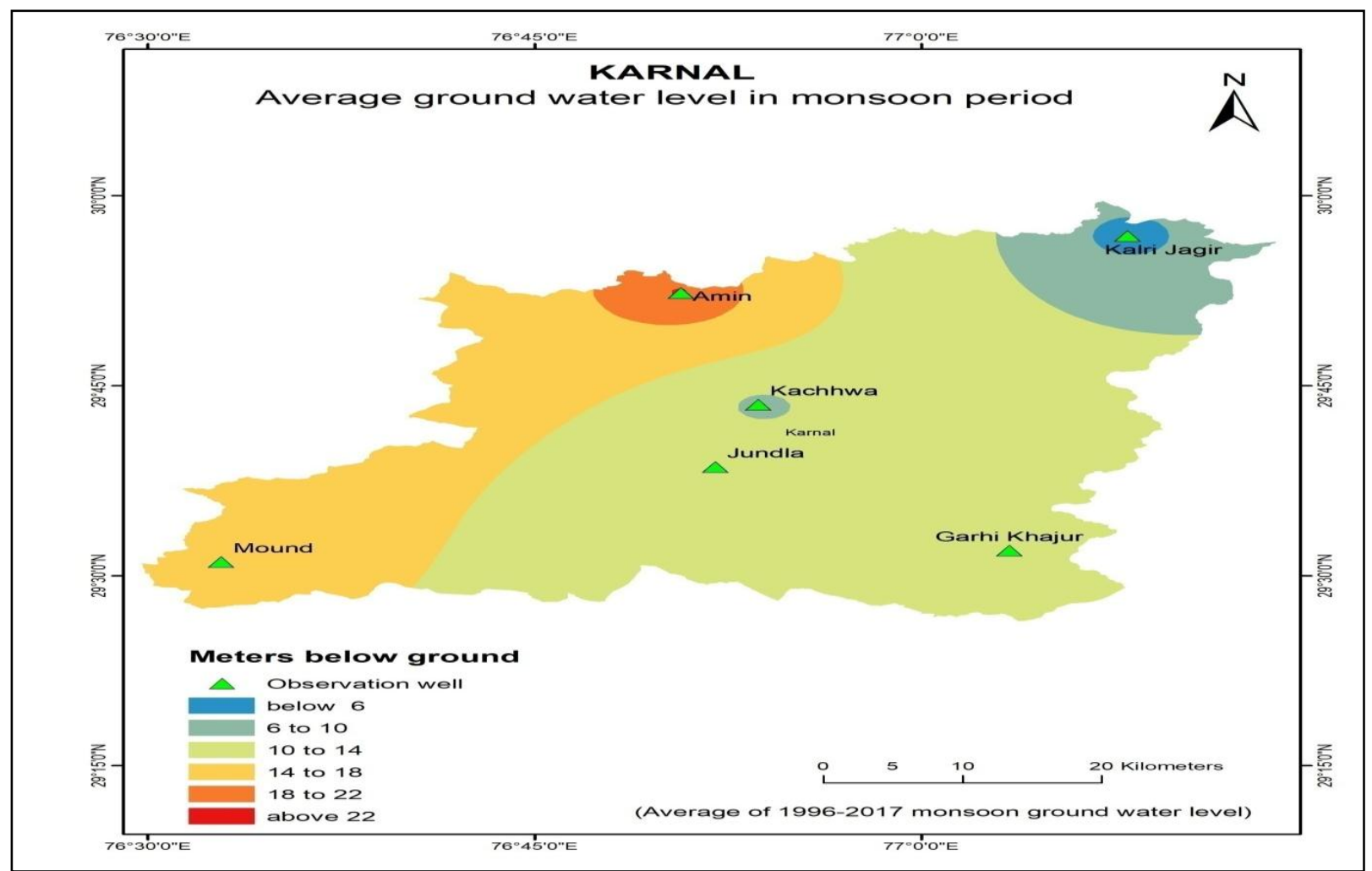

Figure 4. Average Ground Water levels during monsoon period GW level 1996-2017

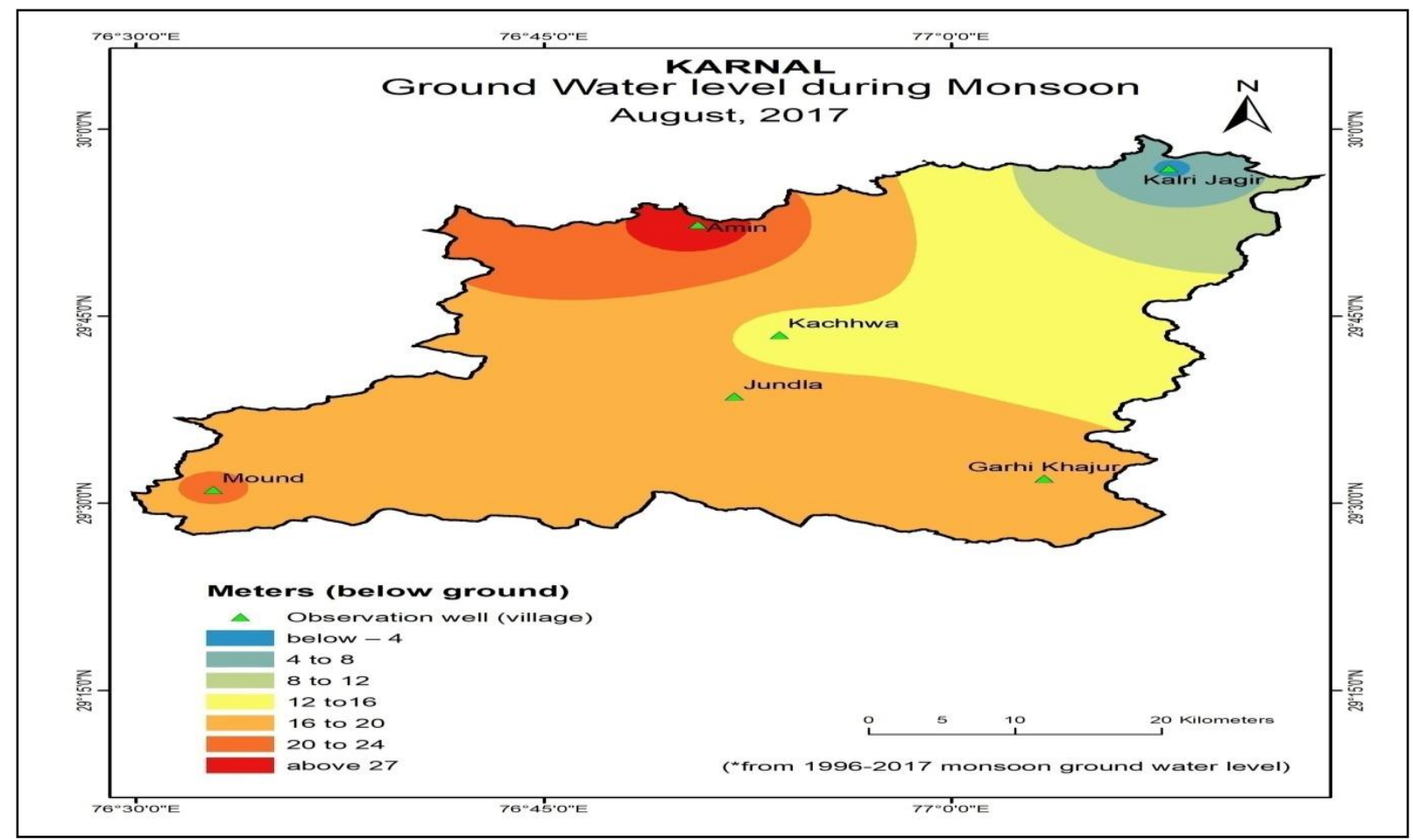

Figure 5. Ground water levels during monsoon 2017 


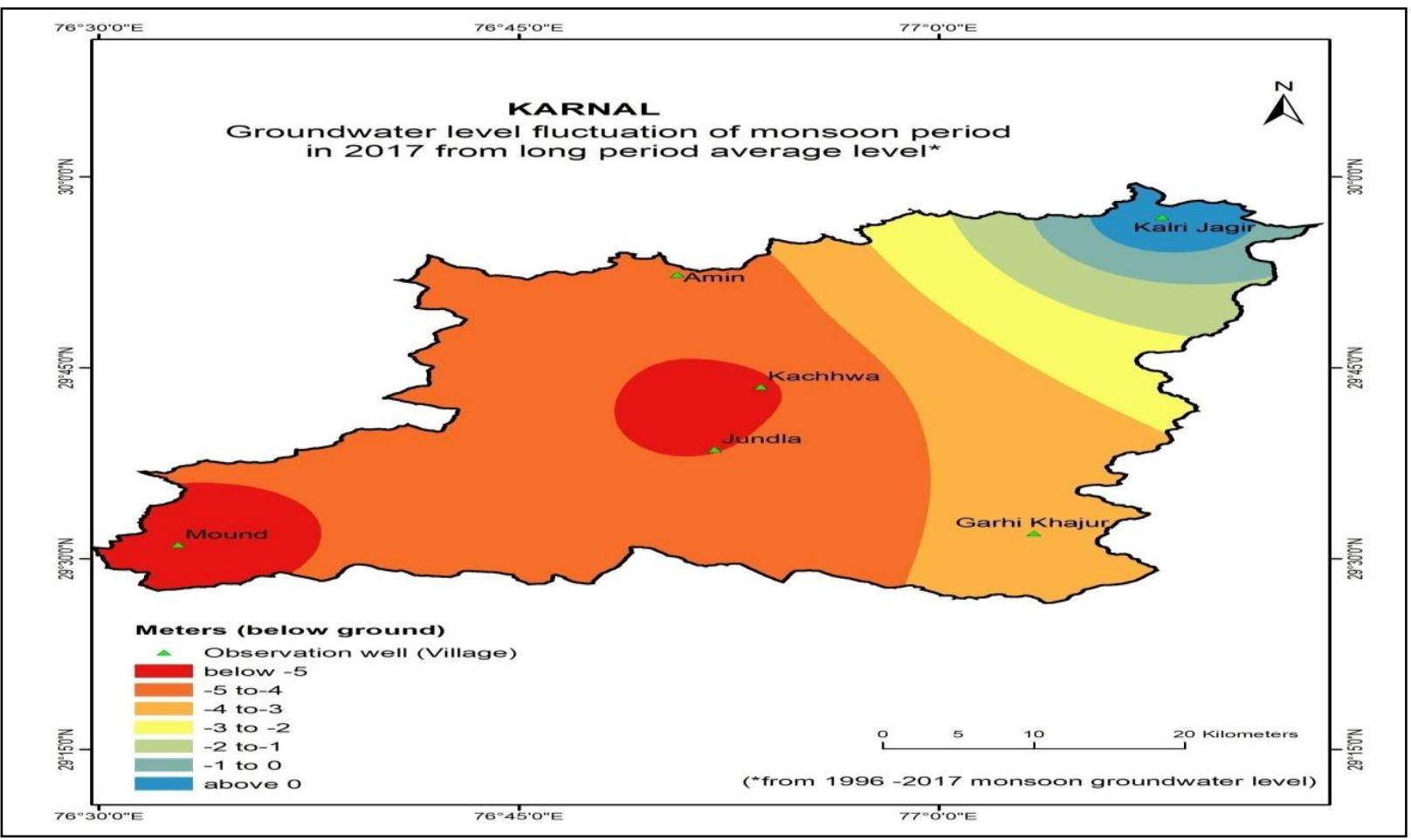

Figure 6. Fluctuations in GW level in Monsoon period 2017 from average.

\section{Conclusion}

The water table of the Karnal district has declined to $16 \mathrm{~m}$ in 2017 , the water table of Indri block has come down to $14.17 \mathrm{~m}$ from $13.41 \mathrm{~m}$ in 2010 , Gharaunda has witnessed a downfall from $18.54 \mathrm{~m}$ in 2010 to $21.42 \mathrm{~m}$ in 2017, in Assandh the water table was 16.97 in 2010, which has reduced to $23.23 \mathrm{~m}$ in 2017. At present, minimum water level of pre-monsoon were observed $4.16 \mathrm{bgl}$ (below groundwater level) at block Indri. In pre-monsoon, rise in water level was found in north part and decline was in south eastern part. Study show that in monsoon, minimum depth of ground water was about $6 \mathrm{~m}$ around Indri block in eastern part. In the north part ground water level was very low and depth was more than $22 \mathrm{~m} \mathrm{bgl}$. Proximity of Yamuna River has influence of ground water along its neighboring blocks.

\section{References}

Anonymous, 2013. Ground water information booklet, Karnal district, Haryana. Central ground water board.
Arnold, G. and Valk V. D. 2005.Water-level fluctuations in North American prairie wetlands, The International Journal of Aquatic Sciences, 539(1): 171-188.

Bhutiani, R., Ram, K., Tyagi, V., Ahamad, F. and Kaushik, P. 2018. Assessment of ground water quality of Laksar block in district Haridwar, Uttarakhand. Environment Conservation Journal 19 (3): 123-128.

Saraf, A., and Choudhary, P. R. 1998. Integrated remote sensing and GIS for ground water exploration and identification of Artificial Recharge site. Int. J. Remo. Sens. 19(10):1825-1841.

Chaudhary, B. S. 2003. Integrated land and water resources management in southern part of Haryana using Remote Sensing and geographical information system (GIS), PH.D Thesis, University of Rajasthan, Jaipur, India. 78 - 79.

Sharma, B. and Saraf, A. K. 2002. study of landuse groundwater relationship using an integrated remote sensing and GIS approached. Procceedings of Map Asia 2002, Asian conference on GIS, GPS, Aerial photography and Remote Sensing, organized by Asian Institute of Technology, Bangkok and CSDMS, New Delhi, held in Bangkok between 7 and 9 August, 2002 